\title{
Nocturia: Prevalence and associated factors in community-dwelling subjects - a population- based study
}

\author{
Rodrigo Cruz \\ Daria Garcia-Rosa² \\ (iD) Carlos Faria ${ }^{3}$
}

1. Mestrado Profissional em Saúde da Mulher e da Criança, Universidade Federal Fluminense - UFF - Niterói, RJ, Brasil 2. Departamento de Epidemiologia e Bioestatística, Instituto de Saúde Coletiva, Universidade Federal Fluminense - UFF - Niterói. RJ, Brasil.

3. Departamento Materno Infantil, Faculdade de Medicina, Universidade Federal Fluminense (UFF). Niterói, RJ, Brasil.

\begin{abstract}
SUMMARY
OBJECTIVES: To assess the prevalence of nocturia and identify factors associated with it in a community-dwelling population.

METHODS: A cross-sectional study was conducted in subjects aged 45 years or more and registered with a Family Doctor Program. Information was collected about nocturia, other urinary symptoms, physical examination, co-morbidities, demographics, socio-economic, and lifestyle factors. Multiple logistics regression models were developed to analyze associated factors for nocturia according to gender and the number of nocturnal micturitions $(\geq 1$ and $\geq 2$ ).

RESULTS: Out of the 661 individuals included in the study, $62.3 \%$ were women. Among the women, the prevalence rates for nocturia $\geq 1$ time and $\geq 2$ times were, respectively, $68.4 \%$ and $49 \%$, whereas, among the men, they were $64.3 \%$ and $43.8 \%$. Among the women, nocturia $\geq 1$ time was associated with brown skin, a higher BMI, lower schooling, and calcium channel blockers(CCB) use, while nocturia $\geq 2$ times showed association with higher BMI, lower schooling, obstructive sleep apnea (OSA), and the use of CCB. Among the men, nocturia $\geq 1$ time was associated positively with age, alcohol intake, and OSA, and negatively with angiotensin receptor blockers and beta-blockers use. Besides, nocturia $\geq 2$ times was associated with age, not having health insurance, and OSA
\end{abstract}

CONCLUSIONS: Nocturia is a condition highly prevalent in the studied population. For the female subjects, a higher BMI, lower schooling, and the use of CCB were associated with nocturia regardless of the definition used, whereas, among the men, that same association was found with age, not having health insurance, and OSA.

KEYWORDS: Aging. Nocturia. Prevalence. Primary Health Care.

\section{INTRODUCTION}

In 2010, a joint ICS and IUGA report on the terminology of female pelvic floor dysfunction defined nocturia as the need to wake up at night one or more times to micturate, and each nocturnal micturition is preceded and followed by sleep. ${ }^{1}$

Based on studies showing that a single episode of nocturia seems not to cause discomfort, this definition was called into question, with the suggestion that nocturia would be clinically significant when there are 2 or more episodes per night. ${ }^{2}$

The incidence of nocturia increases with age, and its prevalence is so high in the elderly that most people often do not consider it a condition worth treating, but rather part of the physiological process of aging. ${ }^{3} \mathrm{~A}$ 
systematic review of the literature showed that 29-59\% of men over 70 years of age reported two or more episodes of nocturnal micturition. The prevalence of women in this same age group varied from 28 to $62 \% .{ }^{4}$

Even if both patients and physicians may consider nocturia to be more of an annoyance than a serious condition, it has been associated with various health problems, in both men and women, such as obesity, hypertension, diabetes mellitus (DM), heart failure, obstructive sleep apnea (OSA), coronary artery disease, a history of stroke, asthma, overactive bladder syndrome, and the use of medications. ${ }^{2,5,6}$

Regarding its etiology, there are specific factors that cause nocturia. In women, it is associated with obesity, the post-menopause period, and a history of $\mathrm{DM}$, hypertension, hysterectomy, and uterine prolapse, among other conditions..$^{5,-9}$ Among men, it is associated with factors such as age, DM, benign prostate hyperplasia, prostate cancer, prostatitis, and the use of antidepressants. ${ }^{5,6}$

Elderly persons with nocturia are at a higher risk of suffering falls and fractures, which tends to increase their morbidity and mortality. ${ }^{10}$ In addition, the condition is also associated with a higher risk of mortality in general, especially in young men and middle-aged men and women, and the survival rate decreases as the number of nocturnal micturitions increases. ${ }^{11}$

Brazilians are undergoing a rapid process of aging, and interest is growing in the study of conditions that affect the health and quality of life of this large population group. A study on the prevalence of lower urinary tract symptoms, including nocturia, conducted in a group of subjects in the north-eastern part of the country, found overall rates of $64.4 \%$ and $71.2 \%$ in men and women, respectively, when the definition used was the presence of one or more nocturnal micturitions. When the definition was two or more micturitions, the rates decreased by $50 \%$. In both cases, the prevalence increased with the age group, but factors associated with nocturia were not studied. ${ }^{12}$

Given that nocturia is a common condition in the elderly that is associated with a poorer quality of life and the risk of death, and may be overlooked, it is essential that we alert healthcare professionals to the problem, mainly those who provide health care to the elderly. ${ }^{13}$

The objectives of the present study were to assess the prevalence of nocturia and identify demographic, socio-economic, lifestyle, and clinical factors associated with this condition.

\section{METHODS}

\section{Study design}

This study is part of the Digitalis study, a cross-sectional investigation of the prevalence of chronic diseases and their association with risk factors, using a random, two-stage sample (sector and individuals in the sector) of a group of people aged 45 years or more registered with the Niteroi Family Doctor Program (FDP), in the State of Rio de Janeiro, Brasil. ${ }^{14}$ The sample size was calculated to estimate the prevalence and the measures of association, taking the feasibility of the study into consideration. Our calculations predicted that it would be possible to assess 600 subjects, plus $10 \%$ for incomplete assessments (losses), in 18 months.

The units (sectors) to be included in the study were randomly selected from the official list of FDP sectors. For each sector, approximately 80 subjects of both genders, between 45 and 99 years of age, were randomly selected from the records of residents kept on file by the program. It was expected that 30 examinations would be conducted per visit. Thus, it was recommended that 50 residents be invited to participate, to take into account non-attendance, and that 30 other names be collected for possible substitutions.

Visits were carried out from August 2011 to November 2012. The participants responded to a questionnaire asking for information related to co-morbidities and demographics, as well as socio-economic and lifestyle factors. Physicians and nurses were in charge of each patient's medical history and physical examination. Besides, urine and fasting blood samples were collected.

The Digitalis questionnaire investigated the presence of various co-morbidities, including urinary disorders. Among other conditions, patients were asked if they had to get up at night to micturate and, if they gave a positive response, how many times that occurred per night. Individuals who reported waking up to micturate at least once at night were deemed to have nocturia. ${ }^{1}$ Other urinary symptoms, such as the absence of the perception of the desire to void (the ability to recognize the sensations of bladder filling), the inability to reach the toilet in time (meaning that they had a strong desire to void and urine loss before reaching the toilet), stress urinary incontinence (SUI), defined as involuntary urine loss on sneezing or coughing, the inability to initiate or inhibit voiding, and the inability to completely empty the bladder were also investigated.

Skin color was classified by the participants 
themselves as black, brown, or white.

Subjects with blood pressure $\geq 140 \mathrm{mmHg}$ (systolic) or $\geq 90 \mathrm{mmHg}$ (diastolic) were considered hypertensive, as were those who reported using anti-hypertensive drugs. Participants whose fasting glucose was $\geq 126 \mathrm{mg} / \mathrm{dL}$ and those who reported oral use of hypoglycemic agents and/or insulin were considered to be diabetic.

The Digitalis questionnaire also included questions about whether alcoholic beverages were consumed and with what frequency. Men who consumed, on average, more than two daily doses of alcohol, or women who consumed more than one dose, were considered to be at-risk drinkers.

Chronic kidney disease (CKD) was defined using the KDIGO criteria, and heart failure according to the guidelines of the Brazilian Cardiology Society for chronic heart failure. ${ }^{15,16}$

The risk of having OSA was assessed using the Brazilian version of the Berlin Questionnaire. ${ }^{17}$ That questionnaire contains 19 items, divided into three categories: a history of snoring and apnea, daytime drowsiness, and hypertension or obesity. Subjects who had scores in at least two of the symptom categories were deemed to be at high risk for Obstructive Sleep Apnea Syndrome. ${ }^{17}$

For the classification of depression, the responses from the Patient Health Questionnaire-9 (PHQ-9) were used. Subjects with a score of 3,4 or 5 (moderate, moderately severe, and severe depression) were considered to be positive. ${ }^{18}$

Body mass index (BMI) was calculated as the ratio of weight in kilograms to height in square meters. Patients with a BMI $(\mathrm{kg} / \mathrm{m} 2) \geq 30$ were considered to be obese.

\section{STATISTICAL ANALYSIS}

Our analyses were done separately for men and women.

The continuous variables were expressed as mean \pm standard deviation (SD) in the event of normal distribution. Category variables were expressed as absolute and relative frequencies. Comparisons between the groups were done using the Student t-test. Frequencies were compared using Pearson's chi-square test, with consistency correction using Fisher's exact test, whenever necessary.

Measures of association were calculated based on two different diagnoses of nocturia: one or more episodes per night, and two or more episodes per night, in the latter, using none or one episode per night as the control group for purposes of comparison.

Multiple regression models were developed to analyze associated factors for nocturia using those variables that presented a p-value $\leq 0.10$ in the univariate analysis. We thus calculated the odds ratios (OR) and their confidence intervals at 95\% (CI95). All the multivariate analyses were done taking a p-value $\leq 0.05$ as statistically significant.

Statistical analysis was done using SPSS software, version 23.0 for Windows (IBM, Chicago, USA).

\section{RESULTS}

The study included 661 subjects, of which 412 (62.3\%) were women, and 286 (43.3\%) were more than 60 years old.

Based on the ICS/IUGA definition, 444 (67.2\%) of the patients had nocturia. However, when the symptom of nocturia was considered to be the presence of two or more nocturnal micturitions, its frequency dropped to $47 \%$ (311 cases).

Among the women, we found the prevalence of nocturia to be $68.4 \%$ (one or more nocturnal micturitions) and $49 \%$ (two or more). Among the men, we found frequency rates of $64.3 \%$ and $43.8 \%$, based on the definition used.

Among the female subjects, there was an association $(p \leq 0.10)$ between the occurrence of nocturia (one or more nocturnal micturitions) and the variables of skin color, low level of education, hypertension, DM, BMI (the higher the BMI, the higher the occurrence), symptoms of the inability to reach the toilet in time, SUI, and the use of calcium channel blockers (CCB), beta-blockers, glibenclamide, metformin, and insulin. (Table 1).

When these variables were subjected to multiple logistic regression analyses, we found that the presence of at least one nocturnal micturition showed a positive, independent association with brown skin color, higher BMI, low level of education, and the use of CCB. (Table 2)

Also in the female subjects, when the criterion for nocturia was two or more nocturnal micturitions, we found an association with a low level of education, BMI (the higher the BMI, the higher the rate), hypertension, DM, depression, SUI, a higher risk for OSA and the use of CCB, beta-blockers, ACEI, diuretics, glibenclamide, and metformin (Table 1). 
TABLE 1. ASSOCIATION OF DEMOGRAPHIC FACTORS, COMORBIDITIES AND MEDICINE USE WITH NOCTURIA $\geq 1$ OR $\geq 2$ NOCTURNAL MICTURITIONS ACCORDING TO THE GENDER IN COMMUNITYDWELLING SUBJECTS AGED 45 OR MORE FROM THE NITERÓI FAMILY DOCTOR PROGRAM, RIO DE JANEIRO, BRASIL.

\begin{tabular}{|c|c|c|c|c|}
\hline \multirow[b]{2}{*}{ Nocturnal micturions } & \multicolumn{2}{|l|}{ Women } & \multicolumn{2}{|l|}{ Men } \\
\hline & $\geq 1^{\mathrm{a}}$ & $\geq 2^{b}$ & $\geq 1^{a}$ & $\geq 2^{b}$ \\
\hline Age & $P=0.25$ & $P=0.23$ & $P=0.02$ & $P<0.001$ \\
\hline Mean \pm SD & $59,66 \pm 10,13$ & $59,88 \pm 10,08$ & $60,71 \pm 10,54$ & $61,91 \pm 10,85$ \\
\hline $\mathrm{BMI}$ & $P<0.001$ & $P<0.001$ & $P=0.63$ & $P=0.62$ \\
\hline Mean \pm SD & $29,58 \pm 5,75$ & $29,78 \pm 5,87$ & $26,61 \pm 4,82$ & $26,33 \pm 4,66$ \\
\hline Skin color & $P=0.095$ & $P=0.84$ & $P=0.18$ & $P=0.005$ \\
\hline White & $98(68.1 \%)$ & $71(49.3 \%)$ & $56(59.6 \%)$ & $31(33 \%)$ \\
\hline Brown & $112(74.2 \%)$ & $75(50 \%)$ & $68(63.6 \%)$ & $48(44.9 \%)$ \\
\hline Black & $71(62.3 \%)$ & $53(46.9 \%)$ & $34(75.6 \%)$ & $28(62.2 \%)$ \\
\hline Schooling & 0.047 & $P=0.007$ & $P=0.034$ & $P=0.007$ \\
\hline Up to 4 yrs & $135(74.2 \%)$ & $103(56.6 \%)$ & $70(72.2 \%)$ & $53(54.6 \%)$ \\
\hline$\geq 5 \mathrm{yrs}$ & $149(65.1 \%)$ & $99(43.2 \%)$ & $89(58.9 \%)$ & $56(37.1 \%)$ \\
\hline Health insurance & 0.23 & $P=0.13$ & 0.087 & 0.013 \\
\hline No & $246(69.9 \%)$ & $177(50.3 \%)$ & $134(66.3 \%)$ & $95(47 \%)$ \\
\hline Yes & $36(62.1 \%)$ & $23(39.7 \%)$ & $22(52.4 \%)$ & $11(26.2 \%)$ \\
\hline Alcohol (risk dose) & 0.73 & 0.26 & $P=0.067$ & $P=0.65$ \\
\hline No & $266(68.7 \%)$ & $187(48.3 \%)$ & $132(62 \%)$ & $92(43.2 \%)$ \\
\hline Yes & $18(72 \%)$ & $15(60 \%)$ & $28(77.8 \%)$ & $17(47.2 \%)$ \\
\hline Hypertension & 0.001 & 0.001 & 0.99 & 0.20 \\
\hline No & $54(55.7 \%)$ & $33(34 \%)$ & $54(64.3 \%)$ & $32(38.1 \%)$ \\
\hline Yes & $230(73 \%)$ & 169(53.7\%) & 106(64.2\%) & $77(46.7 \%)$ \\
\hline Diabetes & 0.002 & 0.001 & 0.29 & 0.20 \\
\hline No & $195(65 \%)$ & 134(44.7) & 118(62.4) & $78(41.3)$ \\
\hline Yes & $85(81)$ & 66(62.9) & $40(70.2)$ & 29(50.9) \\
\hline Depression & 0.85 & 0.10 & 0.13 & 0.039 \\
\hline No & $203(68.6)$ & 138(46.6) & 138(63) & $92(42)$ \\
\hline Yes & $80(69.6 \%)$ & 64(55.7) & $21(77.8)$ & $17(63)$ \\
\hline ACE K & 0.100 & 0.063 & 0.032 & 0.100 \\
\hline No & 188(66.4) & 130(45.9) & 101(59.8) & $68(40.2)$ \\
\hline Yes & 96(74.4) & 72(55.8) & 59(73.8) & $41(51.3)$ \\
\hline $\mathrm{ARB}^{\mathrm{d}}$ & 0.79 & 0.37 & 0.001 & 0.12 \\
\hline No & 248(68.7) & 174(48.2) & 157(66.5) & 106(44.9) \\
\hline Yes & $36(70.6)$ & 28(54.9) & $3(23.1)$ & 3(23.1) \\
\hline $\mathrm{CCB}^{\mathrm{e}}$ & 0.002 & 0.000 & 0.58 & 0.68 \\
\hline No & $228(65.9)$ & 155(44.8) & 144(63.7) & 98(43.4) \\
\hline Yes & $56(84.8)$ & $47(71.2)$ & 16(69.6) & $11(47.8)$ \\
\hline Beta-blockers & 0.020 & 0.004 & 0.002 & 0.008 \\
\hline No & $224(66.5)$ & 154(45.7) & 149(67.7) & 103(46.8) \\
\hline Yes & $60(80)$ & $48(64)$ & $11(37.9)$ & $6(20.7)$ \\
\hline Diuretics & 0.850 & 0.067 & 0.440 & 0.059 \\
\hline No & 168(68.6) & 111(45.3) & 117(62.9) & $75(40.3)$ \\
\hline Yes & 116(69.5) & 91(54.5) & $43(68.3)$ & $34(54)$ \\
\hline Kidney diseases & 0.51 & 0.12 & 0.12 & 0.03 \\
\hline $\mathrm{KDIGO}^{f} 1$ and 2 & $242(68.6)$ & 168(47.6) & 136(62.7) & $89(41)$ \\
\hline KDIGO 3,4 and 5 & $33(73.3)$ & $27(60)$ & $21(77.8)$ & $17(63)$ \\
\hline High risk for OSAg & 0.27 & 0.044 & 0.045 & 0.012 \\
\hline No & $231(68.3)$ & 158(46.7) & $123(60.6)$ & $80(39.4)$ \\
\hline Yes & $38(76)$ & $31(62)$ & $21(80.8)$ & $17(65.4)$ \\
\hline
\end{tabular}




\begin{tabular}{|c|c|c|c|c|}
\hline \multirow[b]{2}{*}{ Nocturnal micturions } & \multicolumn{2}{|l|}{ Women } & \multicolumn{2}{|l|}{ Men } \\
\hline & $\geq 1^{a}$ & $\geq 2^{b}$ & $\geq 1^{\mathrm{a}}$ & $\geq 2^{b}$ \\
\hline Inability to reach the toilet in time & 0.092 & 0.42 & 0.31 & 0.013 \\
\hline No & $254(68.3)$ & $179(48.1)$ & $139(62.9)$ & $92(41.6)$ \\
\hline Yes & $18(85.7)$ & $12(57.1)$ & 10(76.9) & $10(76.9)$ \\
\hline SUI ${ }^{h}$ & 0.054 & 0.063 & 0.49 & 0.33 \\
\hline Não & $159(65.7)$ & $109(45)$ & $131(64.5)$ & $86(42.4)$ \\
\hline Sim & $111(75)$ & $81(54.7)$ & $18(58.1)$ & $16(51.6)$ \\
\hline Glibenclamide use & 0.037 & 0.065 & 0.97 & 0.91 \\
\hline No & $259(67.6)$ & $183(47.8)$ & $153(64.3)$ & $104(43.7)$ \\
\hline Yes & $25(86.2)$ & $19(65.5)$ & $7(63.6)$ & $5(45.5)$ \\
\hline Metformin use & 0.002 & 0.001 & 0.76 & 0.57 \\
\hline No & $234(66.1)$ & $162(45.8)$ & $144(64.6)$ & $99(44.4)$ \\
\hline Yes & $50(86.2)$ & $40(69)$ & $16(61.5)$ & $10(38.5)$ \\
\hline Insulin use & 0.055 & 0.14 & 0.93 & 0.42 \\
\hline No & $276(68.3)$ & $196(48.5)$ & $158(64.2)$ & $107(43.5)$ \\
\hline Yes & $8(100)$ & $6(75)$ & $2(66.7)$ & $2(66.7)$ \\
\hline Prostate disease & - & - & 0.39 & 0.085 \\
\hline No & - & - & $142(63.4)$ & $94(42)$ \\
\hline Yes & - & - & 18(72) & $15(60)$ \\
\hline
\end{tabular}

Age and BMI - Student-test; others variables: Pearson Chi-square test.

Legend: $a$ The tests refer to the comparison between nocturia $\geq 1$ nocturnal micturitions versus no nocturnal micturition for each gender. $b$ The tests refer to the comparison between nocturia $\geq 2$ nocturnal micturitions versus $<2$ nocturnal micturition for each gender. $c$ ACEI - angiotensin-converting enzyme inhibitors; d ARB - angiotensin receptor blockers e CCB - calcium channel blockers; f KDIGO - Kidney Disease: Improving Global Outcomes classification of chronic kidney disease; g OSA - obstructive sleep apnea; h SUI - Stress urinary incontinence

The multiple logistics regression analysis, in turn, showed a positive, independent association with a higher BMI, a low level of education, a higher risk for OSA, and the use of CCB. (Table 3)

Among the male subjects, there was an association $(p \leq 0.10)$ between the occurrence of nocturia (one or more nocturnal micturitions) and the variables of age (the older the age, the higher the occurrence), a low level of education, not having health insurance, the intake of risky levels of alcohol, a higher risk for OSA, the use of ACEI, the use of angiotensin receptor blockers (ARB) (lower chance) and beta-blockers (lower chance). (Table 1).

When the variables were subjected to multiple logistic regression analysis, we found that the presence of at least one nocturnal micturition showed a positive, independent association with age, intake of risky levels of alcohol and a higher risk for OSA, and a negative, independent association with the use of ARB and beta-blockers. (Table 4)

When two or more nocturnal micturitions was used as the criterion, we found an association with age (the older, the higher the chance), low level of education, not having health insurance, skin color, chronic kidney disease, depression, the use of diuretics, beta-blockers (lower chance), the inability to micturate in proper places, a higher risk for OSA, and a history of prostate disease (Table 1). The multiple logistics regression analysis showed a positive, independent association with higher age, not having health insurance, and a higher risk for OSA. (Table 5)

The variables heart failure, absence of the perception of the desire to void, inability to initiate or inhibit

TABLE 2. ADJUSTED ODDS RATIOS (MULTIPLE LOGISTIC ANALYSIS) FOR FACTORS ASSOCIATED WITH $\geq 1$ NOCTURNAL MICTURITIONS IN IN COMMUNITYDWELLING WOMEN AGED 45 OR MORE FROM THE NITERÓI FAMILY DOCTOR PROGRAM. RIO DE JANEIRO. BRASIL.

\begin{tabular}{l|l} 
Variable & ORa $(95 \% \mathrm{Cl})$ \\
\hline BMI $^{a}$ & $1.09(1.04-1.15) p<0.01$ \\
\hline Skin color & \\
\hline Black & 1 \\
\hline White & $1.72(0.97-3.03) p=0.06$ \\
\hline Brown & $2.23(1.24-4.01) p<0.01$ \\
\hline Schooling & $P=0.01$ \\
\hline Up to 4 yrs & $1.84(1.14-2.95)$ \\
\hline$\geq 5$ yrs & 1 \\
\hline CCB ${ }^{b}$ use & $P<0.01$ \\
\hline Yes & $3.20(1.47-6.97)$ \\
\hline No & 1 \\
\hline
\end{tabular}

Legend: a BMI - body mass index; b CCB - calcium channel blockers 
TABLE 3. ADJUSTED ODDS RATIOS (MULTIPLE LOGISTIC ANALYSIS) FOR FACTORS ASSOCIATED WITH $\geq 2$ NOCTURNAL MICTURITIONS IN IN COMMUNITYDWELLING WOMEN AGED 45 OR MORE FROM THE NITERÓI FAMILY DOCTOR PROGRAM. RIO DE JANEIRO. BRASIL.

\begin{tabular}{|l|l}
\hline Variable & $\mathrm{ORa}(95 \% \mathrm{Cl})$ \\
\hline BMI $^{a}$ & $1.06(1.02-1.10) p<0.01$ \\
\hline High risk for OSA & $\mathrm{P}<0.05$ \\
\hline Yes & $2.05(1.06-3.96)$ \\
\hline No & 1 \\
\hline Schooling & $\mathrm{P}<0.01$ \\
\hline Up to 4 yrs & $1.94(1.26-2.99)$ \\
\hline$\geq 5$ yrs & 1 \\
\hline CCB use & $\mathrm{P}<0.01$ \\
\hline Yes & $3.10(1.67-5.77)$ \\
\hline No & 1 \\
\hline & Legend: a BMI - body mass index; b CCB - calcium channel blockers
\end{tabular}

TABLE 4. ADJUSTED ODDS RATIOS (MULTIPLE LOGISTIC ANALYSIS) FOR FACTORS ASSOCIATED WITH $\geq 1$ NOCTURNAL MICTURITIONS IN IN COMMUNITYDWELLING MEN AGED 45 OR MORE FROM THE NITERÓI FAMILY DOCTOR PROGRAM. RIO DE JANEIRO. BRASIL.

\begin{tabular}{|l|l|}
\hline Variable & ORa $(95 \% \mathrm{Cl})$ \\
\hline Age & $1.04(1.01-1.08) \mathrm{p}<0.01$ \\
\hline Alcohol (risk dose) & $\mathrm{P}<0.05$ \\
\hline Yes & $2.84(1.12-7.20)$ \\
\hline No & 1 \\
\hline ARBa use & $\mathrm{P}<0.05$ \\
\hline Yes & $0.16(0.03-0.75)$ \\
\hline No & 1 \\
\hline Beta blockers use & $\mathrm{P}<0.01$ \\
\hline Yes & $0.18(0.07-0.47)$ \\
\hline No & 1 \\
\hline High risk for OSA & $\mathrm{P}<0.01$ \\
\hline Yes & $4.61(1.46-14.59)$ \\
\hline No & 1 \\
\hline
\end{tabular}

Legend: a ARB - angiotensin receptor blockers; b OSA - obstructive sleep apnea

TABLE 5. ADJUSTED ODDS RATIOS (MULTIPLE LOGISTIC ANALYSIS) FOR FACTORS ASSOCIATED WITH $\geq 2$ NOCTURNAL MICTURITIONS IN IN COMMUNITYDWELLING MEN AGED 45 OR MORE FROM THE NITERÓI FAMILY DOCTOR PROGRAM. RIO DE JANEIRO. BRASIL.

\begin{tabular}{|l|l|}
\hline Variable & ORa $(95 \% \mathrm{Cl})$ \\
\hline Age & $1.05(1.02-1.08) \mathrm{P}<0.01$ \\
\hline High risk for OSA & $\mathrm{P}<0.01$ \\
\hline Yes & $3.22(1.33-7.78)$ \\
\hline No & 1 \\
\hline Health insurance & $\mathrm{P}<0.01$ \\
\hline Yes & $3.35(1.38-8.13)$ \\
\hline No & 1 \\
\hline
\end{tabular}

Legend: a OSA - obstructive sleep apnea voiding, and inability to completely empty the bladder did not present association with any of the study groups (data not shown).

\section{DISCUSSION}

The comparison of the prevalence of nocturia found in the present study and those found in the literature becomes problematic due to the existence of two criteria for defining the condition, the various methods of subject selection (Internet search, medical record data, and interviews with researchers), and different age groups included by the various authors.

The prevalence of nocturia in our study, defined as at least one nocturnal micturition, was similar to that found by Moreira Jr. et al. ${ }^{12}$. However, when two nocturnal micturitions are used, even though there was a decrease in the prevalence rates in both studies, it was less marked in the present study, which may be due to the inclusion of only subjects over age 45 years in the study group. Likewise, when our results are compared with international studies, the prevalence rates are similar in some cases and dissimilar in those where, mainly, the age group of the subjects was lower. $5,6,9,11$

Based on the results obtained, age was an associated factor in men, regardless of the definition of the symptom, and that result is in agreement with the literature. ${ }^{5,8,19}$

That association can be explained by a higher prevalence of co-morbidities and chronic systemic diseases as a man's age increases, especially prostate disorders, for which nocturia is one of the symptoms. Although no association of a history of prostate disorders with nocturia was found in the study group, that may only mean that the subjects were unaware of having prostate disease, but does not rule out the possibility of a subject having it. Furthermore, aging itself may lead to irreversible, age-dependent changes in the lower urinary tract, both functional and structural, that contribute to nocturia. ${ }^{20}$

Based on the results obtained, the higher the BMI, the higher the risk of nocturia in women, which is in agreement with the literature..$^{5-8,21,22}$ Women over age 45 years are in the peri- and postmenopausal periods, in which there is a weight gain due to metabolic changes. Added to that is the association of obesity with chronic diseases and, consequently, the use of medications to treat them, and with an increased risk for OSA, all factors associated with nocturia. ${ }^{23,24}$

Subjects with a higher risk of having OSA also have a higher risk of nocturia, both men and women, 
although for women, in this case, only when it is defined as two or more nocturnal micturition episodes. This finding is in accordance with various other studies. ${ }^{23,25,26}$ Both conditions - OSA and nocturia - are associated with cardiovascular disease, type II diabetes, renal disease, the use of alcohol and smoking, sedentariness, and the use of medications, which may justify the results we obtained.

Some socio-economic variables showed an association with nocturia. An association between low level of education and nocturia was found only in the women, whereas in the men, two or more episodes of nocturnal micturition were associated with not having health insurance. Some studies obtained similar results, while others failed to show these associations. ${ }^{7,919}$ A low level of education is associated with a low socio-economic level, which reduces the likelihood that a person will have private health insurance, which may be a factor related to less access to health care, lower adherence to the treatments for their co-morbidities, and guidelines for changes in lifestyle, which are associated with nocturia. ${ }^{27}$

Concerning the association between drugs and nocturia, only CCB increased the risk of nocturia in women in the multivariate analysis. This finding agrees with that of the BACH study, and the mechanism for this relationship seems to be due to direct blockage of the re-absorption of sodium in the proximal tube of the kidneys, to an increase in the levels of the atrial natriuretic peptide, or even to peripheral edema in the lower members. ${ }^{28,29}$ However, the use of angiotensin blockers appears to be a protective factor for nocturia defined as at least one nocturnal micturition in men. Any condition that causes a pathological increase in angiotensin II may cause primary polydipsia since that substance is a potent central stimulant of thirst. One can thus assume that the beneficial effect of the angiotensin blocker would be less consumption of liquids and thereby a lower production of urine. ${ }^{30}$

Our findings should be interpreted in light of their limitations. Since this was a cross-sectional study, one cannot infer causality. The Digitalis study was designed to be an epidemiological study of chronic disorders, and the results presented here were obtained from a secondary analysis of the data. Other limitations are the sample size, the use of non-standardized questions to identify the presence of nocturia, and the use of a questionnaire for the risk of OSA, without a confirmed diagnosis. However, this study contributes to our knowledge of a condition rarely studied in the Brazilian population, that affects not only the quality of life of the subjects but also their morbidity and risk of death since nocturia is more common in the elderly and related to risks of falls and death. Other strong points are the fact that it was done on the general population, that our analyses were done based on two definitions of nocturia - taking into consideration the influence of socio-economic factors, clinical history and co-morbidities diagnosed by the use of a physical examination and by additional tests.

\section{CONCLUSIONS}

Nocturia is a symptom prevalent in the population studied, regardless of the definition chosen (one or more nocturnal micturitions/two or more nocturnal micturitions), and is slightly more predominant in women.

Among the women, the BMI, a low level of education and the use of calcium channel blockers were associated with nocturia regardless of the definition used, whereas among the men, that same association was found with age, the fact of not having health insurance, and an elevated risk of obstructive sleep apnea.

\section{Authors contribuition}

All authors contributed equally to the work

\section{RESUMO}

OBJETIVOS: Estimar a prevalência de noctúria e identificar fatores demográficos, socioeconômicos, clínicos e de estilo de vida associados ao sintoma em uma população comunitária.

MÉTODO: Estudo transversal em indivíduos com 45 anos ou mais. Foram obtidas informações demográficas, socioeconômicas, sobre noctúria, outros sintomas urinários, exame físico, comorbidades e estilo de vida. As análises foram feitas separadamente de acordo com o gênero e com o número de miç̧ões noturnas ( $\geq 1$ vez e $\geq 2$ vezes).

RESULTADOS: Dentre os 661 indivíduos incluídos, 62,3\% eram mulheres. Entre elas, a prevalência de noctúria $\geq 1$ vez e $\geq 2$ vezes foi, respectivamente, de 68,4\% e 49\%, enquanto entre os homens foi de $64,3 \%$ e 43,8\%. Entre as mulheres, a noctúria $\geq 7$ mostrou associação com cor da pele parda, maior IMC, baixa escolaridade e uso de bloqueadores dos canais de cálcio (BCC), enquanto noctúria $\geq 2$ vezes mostrou associação com maior IMC, baixa escolaridade, apneia obstrutiva do sono (AOS) e uso de BCC. Entre os homens, a noctúria $\geq 1$ vez esteve associada positivamente com idade, ingestão de álcool e AOS, e negativamente com uso 
de bloqueadores dos receptores da angiotensina e de beta-bloqueadores. Além disso, noctúria $\geq 2$ vezes associou-se a idade, não ter plano de saúde e AOS.

CONCLUSÕES: A noctúria é uma condição altamente prevalente na população estudada. Para as mulheres, IMC elevado, baixa escolaridade e uso de BCC estiveram associados com noctúria independente da definição, enquanto que, para os homens, a mesma associação foi identificada com idade, não ter plano de saúde e AOS.

PALAVRAS-CHAVE: Envelhecimento. Noctúria. Prevalência. Atenção primária à saúde.

\section{REFERENCES}

1. Haylen BT, Ridder D, Freeman RM, Swift SE, Berghmans B, Lee J, et al. An International Urogynecological Association (IUGA)/International Continence Society (ICS) joint report on the terminology for female pelvic floor dysfunction. Int Urogynecol J. 2010;21(1):5-26.

2. Mobley DF, Baum N. Etiology, evaluation, and management of nocturia in elderly men and women. Postgrad Med. 2014;126(2):147-53.

3. Kim JW, Moon YT, Kim KD. Nocturia: the circadian voiding disorder. Investig Clin Urol. 2016;57(3):165-73.

4. Weiss JP, Blaivas JG, Bliwise DL, Dmochowski RR, Dubeau CE, Lowe FC, et al. The evaluation and treatment of nocturia: a consensus statement. BJU Int. 2011;108(1):6-21.

5. Madhu C, Coyne K, Hashim H, Chapple C, Milsom I, Kopp Z. Nocturia: risk factors and associated comorbidities; findings from the EpiLUTS study. Int | Clin Pract. 2015;69(12):1508-16.

6. Tikkinen $\mathrm{KAO}$, Auvinen $\mathrm{A}$, Johnson $2^{\text {nd }} \mathrm{TM}$, Weiss JP, Keränen $\mathrm{T}$, Tiitinen $A$, et al. A systematic evaluation of factors associated with nocturia: the population-based FINNO study. Am J Epidemiol. 2009;170(3):361-8.

7. Burgio KL, Johnson $2^{\text {nd }} T M$, Goode PS, Markland AD, Richter HE, Roth DL, et al. Prevalence and correlates of nocturia in community-dwelling older adults. I Am Geriatr Soc. 2010;58(5):861-6.

8. Wang $Y, H u H, X u K$, Zhang $X$, Wang $X, N a Y$, et al. Prevalence, risk factors, and symptom bother of nocturia: a population-based survey in China. World J Urol. 2015;33(5):677-83.

9. Hsu A, Nakagawa S, Walter LC, Van Den Eeden SK, Brown JS, Thom DH, et al. The burden of nocturia among middle-aged and older women. Obstet Gynecol. 2015;125(1):35-43.

10. Vaughan CP, Brown C), Goode PS, Burgio KL, Allman RM, Johnson $2^{\text {nd }}$ TM. The association of nocturia with incident falls in an elderly community-dwelling cohort. Int J Clin Pract. 2010;64(5):577-83.

11. Kupelian V, Fitzgerald MP, Kaplan SA, Norgaard JP, Chiu GR, Rosen RC Association of nocturia and mortality: results from the Third National Health and Nutrition Examination Survey. J Urol. 2011;185(2):571-7.

12. Moreira Jr ED, Neves RCS, Fernandes Neto A, Duarte FG, Moreira TL, Lobo $C F L$, et al. A population-based survey of lower urinary tract symptoms (LUTS) and symptom-specific bother: results from the Brazilian LUTS epidemiology study (BLUES). World J Urol. 2013;31(6):1451-8.

13. Bliwise DL, Rosen RC, Baum N. Impact of nocturia on sleep and quality of life: a brief, selected review for the International Consultation on Incontinence Research Society (ICl-RS) Nocturia Think Tank. Neurourol Urodyn. 2014;33(Suppl 1):S15-8

14. Garcia Rosa ML, Mesquita ET, Jorge AJL, Correia DMS, Lugon JR, Kang HC et al. Prevalence of chronic diseases in individuals assisted by the family health program in Niteroi, Brasil: evaluation of selection bias and protocol. Int J Med Res Health Sci. 2015;4(3):587-96.

15. Kidney Disease: Improving Global Outcomes (KDIGO) CKD Work Group KDIGO 2012 clinical practice guideline for the evaluation and management of chronic kidney disease. Kidney Int (Suppl). 2013;3:1-150.
16. Bocchi EA, Braga FGM, Ferreira SMA, Rohde LEP, Oliveira WA, Almeida DR, et al. III Brazilian guidelines on chronic heart failure. Arq Bras Cardiol. 2009;93(1 Suppl 1):3-70.

17. Silva KV, Rosa MLG, Jorge AJL, Leite AR, Correia DMS, Silva DS, et al. Prevalence of risk for obstructive sleep apnea syndrome and association with risk factors in primary care. Arq Bras Cardiol. 2016;106(6):474-80.

18. Lima Osório F, Vilela Mendes A, Crippa JA, Loureiro SR. Study of the discriminative validity of the PHQ-9 and PHQ-2 in a sample of Brazilian women in the context of primary health care. Perspect Psychiatr Care. 2009;45(3):216-27.

19. Andersson F, Anderson P, Holm-Larsen T, Piercy J, Everaert K, Holbrook T. Assessing the impact of nocturia on health-related quality-of-life and utility: results of an observational survey in adults. J Med Econ. 2016;19(12):1200-6.

20. Kawauchi A, Tanaka Y, Soh J, Ukimura O, Kojima M, Miki T. Causes of nocturnal urinary frequency and reasons for its increase with age in healthy older men. J Urol. 2000;163(1):81-4

21. Vaughan CP, Auvinen $A$, Cartwright $R$, Johnson $2^{\text {nd }} T M$, Tähtinen RM, Ala-Lipasti MA, et al. Impact of obesity on urinary storage symptoms: results from the FINNO study. J Urol. 2013;189(4):1377-82.

22. Oliveira MCE, Varella LRD, Angelo PHM, Micussi MTABC. The relationship between the presence of lower urinary tract symptoms and waist circumference. Diabetes Metab Syndr Obes. 2016;9:207-11.

23. Tufik S, Santos-Silva R, Taddei JA, Bittencourt LRA. Obstructive sleep apnea syndrome in the Sao Paulo Epidemiologic Sleep Study. Sleep Med. 2010;11(5):441-6

24. Al-Safi ZA, Polotsky AJ. Obesity and menopause. Best Pract Res Clin Obstet Gynaecol. 2015;29(4):548-53.

25. Martin SA, Appleton SL, Adams R], Taylor AW, Catcheside PG, Vakulin A, et al. Nocturia, other lower urinary tract symptoms and sleep dysfunction in a community-dwelling cohort of men. Urology. 2016;97:219-26.

26. Chung S-D, Hung S-H, Lin H-C, Tsai M-C, Kao L-T. Obstructive sleep apnea and urological comorbidities in males: a population-based study. Sleep Breath. 2016;20(4):1203-8

27. Audet M, Dumas A, Binette R, Dionne IJ. Women, weight, poverty and menopause: understanding health practices in a context of chronic disease prevention. Sociol Health IIIn. 2017;39(8):1412-26.

28. Hall SA, Chiu GR, Kaufman DW, Wittert GA, Link CL, McKinlay JB. Commonly used antihypertensives and lower urinary tract symptoms: results from the Boston Area Community Health (BACH) Survey. BJU Int. 2012;109(11):1676-84

29. Weiss JP, Blaivas JG, Blanker MH, Bliwise DL, Dmochowski RR, Drake $M$, et al. The New England Research Institutes, Inc. (NERI) Nocturia Advisory Conference 2012: focus on outcomes of therapy. BJU Int. 2013;111(5):700-16.

30. Weiss JP, Bosch JLHR, Drake M, Dmochowski RR, Hashim H, Hijaz A, et al. Nocturia think tank: focus on nocturnal polyuria: ICI-RS 2011. Neurourol Urodyn. 2012;31(3):330-9.

Erratum: Regarding the article "Prevalence and associated factors in community-dwelling subjects - a population-based study" with DOI number: https://doi.org/10.1590/1806-9282.66.6.830, published in Journal of the Brazilian Medical Association, 2020;66(06), page 830, title in the article changed from: Prevalence and associated factors in community-dwelling subjects - a population-based study

To: Nocturia: Prevalence and associated factors in community-dwelling subjects - a population-based study 